\title{
SENYAPAN PADA UJARAN IWAN FALS DI ACARA TALKSHOW KICK ANDY "AKHIRNYA IWAN FALS BICARA"
}

\author{
DIAN LUFIA RAHMAWATI \\ Dosen pada Program Studi PGSD FKIP Universitas Muhammadiyah Palangkaraya
}

\begin{abstract}
Paused phenomenon needs to be studied through research that is useful to add information about the disciplines of speech production psycholinguistics. The focus of this research are: (1) what percentage of paused that occur during Iwan Fals deliver answers?; (2) What kind paused happened?; and (3) what is the reason or cause of paused?

This study used a qualitative approach and descriptive analysis method. The research objectives are recording the show Kick Andy "Finally Iwan Fals Talk" sequel 3/25 uploaded at http// www.youtube.com by nengsalse on February 5, 2010 with the subject of the research is Iwan Fals and the object of research is speech Iwan Fals.

Based on the results of the calculation of the length of time or duration paused contained in the speech Iwan Fals in the show Kick Andy "Finally Iwan Talk", paused occurred for 30 seconds, or $23.8 \%$ of the speaking time for 126 seconds. In speech Iwan Fals paused there are two types, namely paused silent and paused filled. Some of the reasons for the speech paused Iwan Fals, among others: (1) take a breather; (2) already started with the utterance, but in fact the whole sentence is not ready for it; (3) forgotten on certain words are needed; (4) hesitant because remembering past events; (5) The search for the right words to say; and (6) of prudence.
\end{abstract}

Keywords : paused, speech, psycholinguistic

\section{ABSTRAK}

Fenomena senyapan perlu dikaji melalui penelitian yang berguna untuk menambah informasi tentang produksi ujaran pada disiplin ilmu psikolinguistik. Fokus penelitian ini adalah : (1) berapa prosentase senyapan yang terjadi selama Iwan Fals menyampaikan jawaban?; (2) apa saja jenis senyapan yang terjadi?; dan (3) apa yang menjadi alasan atau penyebab terjadinya senyapan?

Penelitian ini menggunakan pendekatan kualitatif dan metode analisis deskriptif. Sasaran penelitian adalah hasil rekaman acara Kick Andy "Akhirnya Iwan Fals Bicara" sekuel 3/25 yang diunggah di http//www.youtube.com oleh nengsalse pada tanggal 5 Februari 2010 dengan subjek penelitian adalah Iwan Fals dan objek penelitian adalah ujaran Iwan Fals.

Berdasarkan hasil perhitungan lama waktu atau durasi senyapan yang terdapat pada ujaran Iwan Fals di acara Kick Andy "Akhirnya Iwan Bicara", senyapan terjadi selama 30 detik atau sebesar 23,8\% dari waktu bicaranya selama 126 detik. Pada ujaran Iwan Fals terdapat dua jenis senyapan, yaitu senyapan diam dan senyapan terisi. Beberapa alasan terjadinya senyapan pada ujaran Iwan Fals antara lain: (1) mengambil nafas; (2) terlanjur mulai dengan ujarannya, tetapi sebenarnya belum siap untuk seluruh kalimat itu; (3) lupa pada kata-kata tertentu yang diperlukan; (4) ragu-ragu karena mengingat-ingat kejadian di masa lampau; (5) mencari kata-kata yang tepat untuk disampaikan; dan (6) kehati-hatian.

Kata kunci: senyapan, ujaran, psikolinguistik

\section{PENDAHULUAN}

Dewasa ini program talkshow dapat dikatakan sedang naik daun sehingga marak disiarkan oleh televisi baik Lembaga Penyiaran Publik TVRI maupun televisi swasta. Dari sekian banyak acara talkshow yang pada umumnya disiarkan secara langsung (live), Kick Andy adalah salah satu yang "tidak biasa", karena selalu menghadirkan orang-orang yang patut 
untuk diteladani karena kreatifitasnya yang luas, kemauannya yang keras dan dedikasinya yang tinggi, meskipun bagi kalangan umum tidak terlalu dikenal. Episode Kick Andy yang spesial di awal Tahun 2010 yang lalu adalah "Akhirnya Iwan Fals Bicara" yang menghadirkan sosok fenomenal, Iwan Fals. Seperti kita maklumi, musisi dan penyanyi yang bernama asli Virgiawan Listanto itu sangat populer dengan lagu-lagunya yang berisi kritik sosial seperti lagu "Guru Oemar Bakri" dan "Galang Rambu Anarki" di era 1980-an serta lagu "Bongkar" dan Bento" di era 1990-an.

Pada saat menjawab pertanyaanpertanyaan yang berkaitan dengan prestasi yang dicapainya, Iwan Fals cukup terlihat cukup lancar dengan sesekali tersenyum atau tertawa. Hal yang jauh berbeda terjadi ketika pertanyaan menyangkut privasi, peristiwa masa lalu maupun kondisi batin yang melatarbelakangi terciptanya sebuah lagu. Jawaban Iwan untuk yang terakhir ini seringkali terputus-putus, banyak jeda dalam frasa maupun kalimat yang berupa senyapan (pause). Apakah keadaan tersebut dikarenakan Iwan Fals sulit mengingat atau ada hal lain yang menjadi hambatan? Apapun alasannya, adanya fenomena senyapan perlu dikaji lebih mendalam melalui penelitian yang berguna untuk menambah informasi tentang produksi ujaran pada disiplin ilmu psikolinguistik. Fokus penelitian ini adalah : (1) berapa prosentase senyapan yang terjadi selama Iwan Fals menyampaikan jawaban?; (2) apa saja jenis senyapan yang terjadi?; dan (3) apa yang menjadi alasan atau penyebab terjadinya senyapan?

\section{METODOLOGI}

Penelitian ini menggunakan pendekatan kualitatif. Penulis berusaha mencermati kata demi kata yang diujarkan oleh orang yang diwawancara. Dardjowidjojo (2003) mengatakan bahwa studi mengenai produksi kalimat hanya dapat dilakukan secara tidak langsung dengan cara mengobservasi kalimat yang diujarkan. Analisis masalah dalam tulisan ini menggunakan metode deskriptif. Metode deskriptif berusaha menggambarkan atau menjelaskan peristiwa dan kejadian yang ada pada masa sekarang (Sudjana, 1999:52). Sasaran penelitian adalah hasil rekaman acara Kick Andy "Akhirnya Iwan Fals Bicara" sekuel $3 / 25$ yang diunggah di http//www.youtube.com oleh nengsalse pada tanggal 5 Februari 2010 dengan subjek penelitian adalah Iwan Fals sebagai bintang tamu pada acara tersebut dan objek penelitian adalah ujaran Iwan Fals.

\section{PEMBAHASAN}

\section{Komprehensi dan Produksi dalam Psikolinguistik}

Psikolinguistik adalah ilmu yang mempelajari proses-proses mental yang dilalui oleh manusia dalam berbahasa. Secara rinci psikolinguistik mempelajari empat topik utama yaitu (a) komprehensi, yakni proses-proses mental yang dilalui oleh manusia sehingga mereka dapat menangkap apa yang dikatakan orang dan memahami apa yang dimaksud, (b) produksi, yakni, proses-proses mental pada diri kita yang membuat kita dapat berujar seperti yang kita ujarkan, (c) landasan biologis serta neurologis yang membuat manusia bisa berbahasa, dan (d) pemerolehan bahasa, yakni, bagaimana anak memperoleh bahasa mereka (Dardjowidjojo, 2010).

Dari sudut pandang ilmu psikolinguistik, ada dua macam komprehensi (Clark \& Clark, 
1977). Pertama, komprehensi yang berkaitan dengan pemahaman atas ujaran yang kita dengar. Kedua, komprehensi yang berkaitan dengan tindakan yang perlu dilakukan setelah pemahaman itu terjadi. Untuk macam yang pertama, komprehensi dapat didefinisikan sebagai suatu proses mental yaitu pendengar mempersepsi bunyi yang dikeluarkan oleh seorang pembicara dan memakai bunyi-bunyi itu untuk membentuk suatu interpretasi tentang apa kiranya yang dimaksud oleh pembicara tadi. Secara mudah dapat dikatakan bahwa komprehensi adalah pembentukan makna dari bunyi. Setelah pemahaman atas ujaran itu terjadi, pendengar menentukan apakah ada tindakan yang perlu dilakukan sesuai dengan apa yang dia pahami. Proses mental ini dinamakan pelaksanaan kalimat (utilization of sentences).

Proses memproduksi ujaran dapat dibagi menjadi empat tingkat: (1) tingkat pesan (message), di mana pesan yang akan disampaikan diproses, (2) tingkat fungsional, di mana bentuk leksikal dipilih lalu diberi peran dan fungsi sintaktik, (3) tingkat posisional, di mana konstituen dibentuk dan afiksasi dilakukan, dan (4) tingkat fonologi, di mana struktur fonologi ujaran itu diwujudkan. Bock dan Levelt menggambarkannya dalam Gambar 1 .

Pada tingkat pesan, pembicara mengumpulkan nosi-nosi dari makna yang ingin disampaikan. Pada tingkat fungsional, yang diproses ada dua hal. Pertama memilih bentuk leksikal yang sesuai dengan pesan yang akan disampaikan dan informasi gramatikal untuk masing-masing bentuk leksikal tersebut. Kedua adalah memberikan fungsi pada kata-kata yang dipilih.
Pada tingkat pemrosesan posisional, diurutkan bentuk leksikal untuk ujaran yang akan dikeluarkan. Pengurutan ini bukan berdasarkan pada jejeran yang linear tetapi pada kesatuan makna yang hierarkhis. Setelah pengurutan selesai, diproseslah afiksasi yang relevan. Hasil pemrosesan posisional 'dikirim' ke tingkat fonologi untuk diwujudkan dalam bentuk bunyi. Pada tahap ini aturan fonotaktik bahasa yang bersangkutan diterapkan. Proses fonologis ini tidak sederhana karena tersangkut pula proses biologis dan neurologis.

Teori mutahir mengenai produksi ujaran mengatakan bahwa ujaran diproses melalui tiga tahap: konseptualisasi, formulasi dan artikulasi (Meyer, 2000; Roelos, 2000). Tahap pesan yang diajukan oleh Bock dan Levelt pada Gambar 1 merupakan salah satu contoh untuk tahap konseptualisasi, yakni, di mana pembicara merencanakan struktur konseptual yang akan disampaikan. Tahap yang dinamakan grammatical encoding pada Gambar 1 itu adalah tahap formulasi, yakni, tahap di mana lema yang cocok diretrif dari leksikon mental kita dan kemudian diberi kategori dan struktur sintaktik serta afiksasinya. Tahap phonological encoding adalah tahap artikulasi, yakni, tahap di mana kerangka serta isi yang sudah jadi itu diwujudkan dalam bentuk bunyi.

Dalam proses memproduksi ujaran orang mulai dari perencanaan mengenai topik yang akan diujarkan, kemudian turun ke kalimat yang akan dipakai, dan turun lagi ke konstituen yang akan dipilih. Setelah itu, barulah dia masuk ke pelaksanaan dari yang akan diujarkan. Ini mencakup rencana artikulasi dan bagaimana 
mengartikulasikannya. Prosedur ini (Clark \& Clark, 1977) dapat diwujudkan dalam skema:

\section{Hubungan antara Komprehensi dan Produksi}

Orang dapat meretrif kata hanya bila dia telah menyimpan kata itu dalam memori dia sebelumnya atau telah ada komprehensi. Oleh sebab itu, masalah produksi tidak dapat dilepaskan dari komprehensi. Produksi merupakan cermin balik dari komprehensi dengan tambahan proses-proses tertentu (Bock \& Levelt, 1994; Bock \& Griffin, 2000). Pada komprehensi orang menerima input untuk kemudian disimpan dalam memori. Pada produksi kata yang tersimpan itu dicari kembali untuk kemudian diujarkan. Untuk mencari kata itu diperlukan proses eliminatif dengan memanfaatkan fitur-fitur yang ada pada kata itu, baik fitur semantik, sintaktik, maupun fonologis.

Kesenyapan dan keraguan dalam ujaran terjadi karena pembicara lupa kata-kata apa yang dia perlukan, atau dia sedang mencari kata yang paling tepat, dan sebagainya. Kesalahan yang berupa kilir lidah menunjukkan bahwa kata ternyata tidak tersimpan secara utuh dan orang harus meramunya (Meyer, 2000).

\section{Rekaman Acara Kick Andy}

Hasil rekaman acara Kick Andy "Akhirnya Iwan Bicara" sekuel 3/25 yang diunggah di http//www.youtube.com oleh nengsalse pada tanggal 5 Februari 2010 berisi tentang proses pembuatan lagu "Bongkar". Wawancara berlangsung dalam suasana yang akrab dan diselingi dengan canda tawa. Acara tersebut berlangsung selama 3 menit dan 46 detik atau setara dengan 226 detik. Andy F. Noya sebagai pembawa acara dan sekaligus sebagai pewawancara menggunakan durasi selama 100 detik dan Iwan Fals sebagai orang yang diwawancarai menggunakan durasi selama 126 detik (data selengkapnya tercantum dalam Lampiran ).

\section{Senyapan (pause)}

Pengujaran yang ideal terwujud dalam suatu bentuk ujaran yang lancar, sejak ujaran itu dimulai sampai ujaran itu selesai. Kata-katanya terangkai dengan rapi, diujarkan dalam suatu urutan yang tidak terputus, dan kalau pun ada senyapan, senyapan itu terjadi pada konstituenkonstituen yang memang memungkinkan untuk disenyapi. Intonasinya pun merupakan suatu kesatuan dari awal sampai akhir. Akan tetapi, ujaran ideal semacam ini tidak selamanya dapat kita buat. Tidak semua orang dapat berbicara selancar ini untuk semua topik pembicaraan.

Pada umumnya orang senyap sebentar, entah untuk bernafas entah untuk keperluan yang lain. Pada waktu berbicara, senyap untuk mengambil nafas sebenarnya tidak banyak hanya sekitar $5 \%$. Senyapan yang lebih umum terjadi adalah pada waktu orang ragu-ragu (hesitation). Kecuali ujaran tersebut telah merupakan klise hafalan, atau ujaran itu telah dipersiapkan dengan baik sebelumnya, umumnya $30-50 \%$ ujaran ditandai oleh senyapan (Aitchison, 1998).

Ketika menjawab pertanyaan-pertanyaan yang diajukan oleh Andy F. Noya, beberapa kalimat atau frasa yang disampaikan Iwan Fals terputus-putus karena adanya senyapan (pause) beberapa saat. Kejadian tersebut terutama yang menyangkut peristiwa yang terjadi di masa lalu dan hal-hal yang berkaitan dengan situasi batin ketika proses pembuatan lagu "Bongkar". Berdasarkan hasil perhitungan lama waktu atau durasi senyapan yang terdapat pada ujaran Iwan 
Fals, diperoleh data durasi senyapan selama 30 detik atau sebesar $23,8 \%$ dari waktu bicara Iwan Fals selama 126 detik. Angka ini tergolong wajar atau umum sebagaimana batasan yang disampaikan oleh Aitchison (1998), yaitu antara $30 \%$ sampai dengan $50 \%$ karena wawancara disiarkan secara langsung (live) dengan pertanyaan yang diajukan maupun konsep jawabannya tidak dipersiapkan sebelumnya.

\section{Jenis Senyapan}

Menurut Dardjowidjojo (2003), ketidaksiapan maupun keberhati-hatian dalam berujar terwujud dalam dua macam senyapan, yaitu (1) senyapan diam dan (2) senyapan terisi. Pada senyapan diam, pembicara berhenti sejenak dan diam saja dan setelah menemukan kata-kata yang dicari dia melanjutkan kalimatnya. Tidak mustahil bahwa proses untuk meretrif kata itu tidak cepat sehingga diisilah senyapan itu dengan sesuatu.

Pada penelitian ini terdapat dua jenis senyapan, yaitu senyapan diam dan senyapan terisi. Beberapa senyapan diam antara lain terdapat dalam kalimat atau frasa dengan cetak miring dan garis bawah berikut ini (kalimat atau frasa dengan cetak tegak dalam kurung adalah ujaran pembawa acara):

1. Ujaran: Dia ada bilang sama istri gue, nanti... udahlah nggak usah nggak usah nggak usah, gitu.

2. Ujaran: Jadi... saya agak... tersentuh itu.

3. Ujaran: Kemudian ada... kasus kaca piring yang... dan ada way jepara itu di lampung.

4. Ujaran: Wah jangan gini dong... dikembangin lagi.

5. Ujaran: Grup itu lahir juga karena... saat itu memang perlu ada yang dibongkar.
6. Ujaran: Ada yang bilang persaingan... sponsor, ada yang bilang... politik saat itu atau... (Pemerintah kurang suka ya) pemerintahan.

Adapun jenis senyapan terisi nampak pada kalimat atau frasa berikut:

1. Ujaran: Gimana kalau ep..., kalau main di acaranya apa ..eh... (Kick Andy) Kick Andy.

2. Ujaran: Terus ya..., karena bukan apa apa, emang.

3. Ujaran: Tapi, ya... memang memang... ya, memang.... ya nggak biasalah acara acara kayak gini, gitu.

4. Ujaran: Eh... waktu saya tinggal di Condet tahun berapa itu, tahun... delapan.... sembilah, ya delapan sembilan... delapan sembilan mungkin.

5. Ujaran: Waktu itu ada... apa, cerita tentang kedung ombo.

6. Ujaran: Lagu itu seperti itu, kemudian eh... saya dengerin sama jabo.

7. Ujaran: Akhirnya kata-kata itu di... apa, di... diganti dengan 'penindasan serta' itu tadi.

8. Ujaran: Eh, e.. hubungannya sama swami waktu itu ada grup.

9. Ujaran: Saya pembatalan seratus kota dulu di... di..., di... di... (Kekecewaan Anda waktu itu) ya, ada ada ada kekecewaan itu.

10. Ujaran: lya, sebenarnya sih lebih... iya, dari luar, tapi, ternyata eh... justru faktor pembongkar yang ada di dalem itu yang juga justru lebih penting. Eh... apa... eh...... iwan versus iwanlah, kayak gitu itu.

11. Ujaran: Dalam ... dalam...

Pada bahasa Indonesia, kata-kata seperti anu, apa itu, siapa itu sering dipakai sebagai pengisi. Orang juga sering mengisi senyapan ini 
dengan bunyi-bunyi tertentu seperti eh dan uh yang hanya sekedar merupakan pengisi belaka. Ada juga pembicara seperti penyiar televisi yang yang membuat kekeliruan akan memperbaiki kekeliruan itu dengan memakai, misalnya, frasa maaf, atau maksud kami (Dardjowidjojo, 2003). Untuk kasus ujaran Iwan Fals di atas, isi senyapan itu antara lain eh, e, apa, berapa itu, ep, ya, iya atau pengulangan kata seperti memang memang ya memang, di ... di... di... di..., ada ada ada, dan dalam... dalam.

\section{Penyebab Terjadinya Senyapan}

Dardjowidjojo (2003) mengatakan bahwa pada umumnya orang senyap sebentar, entah untuk bernafas entah untuk keperluan yang lain. Ada berbagai alasan mengapa orang senyap. Pertama, orang senyap karena dia telah terlanjur mulai dengan ujarannya, tetapi sebenarnya dia belum siap untuk seluruh kalimat itu. Karena itu, dia senyap sejenak untuk mencari kata atau katakata untuk melanjutkan ujarannya. Kedua, bisa juga kesenyapan seperti ini terjadi karena dia lupa akan kata-kata yang dia perlukan. Karena itu, dia harus mencarinya untuk melanjutkan ujarannya. Kemungkinan ketiga adalah bahwa dia harus sangat berhati-hati dalam memilih kata agar dampaknya pada pendengar atau publik tidak, misalnya, menghebohkan. Tipe ketiga ini umumnya terjadi pada pejabat publik atau kaum politikus yang harus berhati-hati memilih katakatanya.

Dari hasil penelitian, beberapa alasan terjadinya senyapan pada ujaran Iwan Fals antara lain:
1. Mengambil nafas.

Ujaran : Wah jangan gini dong... dikembangin lagi; kemudian eh... saya dengerin sama jabo.

2. Terlanjur mulai dengan ujarannya, tetapi sebenarnya belum siap untuk seluruh kalimat itu.

Ujaran: Kemudian ada... kasus kaca piring yang... dan ada way jepara itu di lampung; Terus ya..., karena bukan apa apa, emang; Akhirnya kata-kata itu di... apa, di... diganti dengan 'penindasan serta' itu tadi.

3. Lupa pada kata-kata tertentu yang diperlukan.

Ujaran: Gimana kalau ep..., kalau main di acaranya apa ..eh... (Kick Andy) Kick Andy.

4. Ragu-ragu karena mengingat-ingat kejadian di masa lampau.

Ujaran: Eh... waktu saya tinggal di condet tahun berapa itu, tahun... delapan.... sembilah, ya delapan sembilan... delapan sembilan mungkin; Saya pembatalan seratus kota dulu di...di..., di...di....

5. Mencari kata-kata yang tepat untuk disampaikan.

Ujaran: Tapi, ya... memang memang... ya, memang.... ya nggak biasalah acara acara kayak gini gitu; Grup itu lahir juga karena... saat itu memang perlu ada yang dibongkar; lya, sebenarnya sih lebih... iya, dari luar, tapi, ternyata eh... justru faktor pembongkar yang ada di dalem itu yang juga justru lebih penting. Eh... apa... eh..... iwan versus iwanlah, kayak gitu itu.

6. Kehati-hatian.

Ujaran: Ada yang bilang persaingan... sponsor, ada yang bilang... politik saat itu 
atau... (pemerintah kurang suka ya) pemerintahan.

Pada waktu berbicara, senyap untuk mengambil nafas sebenarnya tidak banyak hanya sekitar 5\% (Aitchison, 1998). Senyapan yang lebih umum terjadi adalah pada waktu orang raguragu (hesitation). Pada kasus Iwan Fals di atas, kebanyakan senyapan terjadi karena ragu-ragu terhadap kapan waktu berlangsung kejadian di masa lampau, kata atau istilah apa yang tepat untuk menyampaikan pendapat, dan adanya unsur kehati-hatian.

Senyapan keraguan tidak terdapat di sembarang tempat. Akan tetapi, di mana persisnya belum ada kesepakatan yang mantap di antara para ahli. Ada yang mengatakan bahwa senyapan seperti itu terdapat terutama sesudah kata pertama dalam suatu klausa atau kalimat (Boomer, 1965), tetapi ada pula yang mengatakan bahwa senyapan terdapat terutama sebelum bentuk leksikal yang penting (Aitchison, 1998). Namun demikian, tampaknya ada tempat-tempat di mana para ahli sepakat (Clark \& Clark, 1977), yakni, (1) jeda gramatikal, (2) batas konstituen yang lain, dan (3) sebelum kata utama pertama dalam konstituen.

\section{KESIMPULAN}

Fenomena senyapan perlu dikaji melalui penelitian yang berguna untuk menambah informasi tentang produksi ujaran pada disiplin ilmu psikolinguistik. Berdasarkan hasil perhitungan lama waktu atau durasi senyapan yang terdapat pada ujaran Iwan Fals di acara Kick Andy "Akhirnya Iwan Bicara", senyapan terjadi selama 30 detik atau sebesar $23,8 \%$ dari waktu bicaranya selama 126 detik. Pada ujaran Iwan Fals terdapat dua jenis senyapan, yaitu senyapan diam dan senyapan terisi. Beberapa alasan terjadinya senyapan pada ujaran Iwan Fals antara lain: (1) mengambil nafas; (2) terlanjur mulai dengan ujarannya, tetapi sebenarnya belum siap untuk seluruh kalimat itu; (3) lupa pada kata-kata tertentu yang diperlukan; (4) ragu-ragu karena mengingat-ingat kejadian di masa lampau; (5) mencari kata-kata yang tepat untuk disampaikan; dan (6) kehati-hatian.

\section{DAFTAR PUSTAKA}

Aitchison, Jean. 1998. The Articulate Mammal: An Introduction to Psycholinguistics. London: Routledge.

Bock, Katheryn dan Zensi M. Griffin. 2000. "Producing Words: How Mind Meets Mouth." Dalam Wheeldon, ed. 2000.

Bock, Katheryn dan William Levelt. 1994. "Language Production: Grammatical Encoding." Dalam Gernsbacher, ed. 1994.

Boomer, D. S. 1965. "Hesitation and Grammatical Encoding." Language and Speech, Vol. 8.

Clark, Herbert H. dan Eve V. Clark. 1977. Psychology and Language: An Introduction to Psycholinguistics. New York: Harcourt Brace and Jovanovich, Inc.

Dardjowidjojo, Soenjono. 2010. (Edisi Kedua). Psikolinguistik: Pengantar Pemahaman Bahasa Manusia. Jakarta: Yayasan Obor Indonesia.

Kick Andy: "Akhirnya Iwan Bicara" 3/25. Dalam : http://www.youtube.com (5 Februari 2010)

Meyer, Antje S. 2000. "From Representation in Word Formation." Dalam Wheeldon, ed. 2000.

Roelos, Ardi. 2000. "WEAVER ++ and Other Computational Models of Lemma Retrieval and Word-form Encoding." Dalam Wheeldon, ed. 2000.

Sudjana, Nana. 1999. Penelitian Pendidikan. Jakarta: Rineka Cipta. 


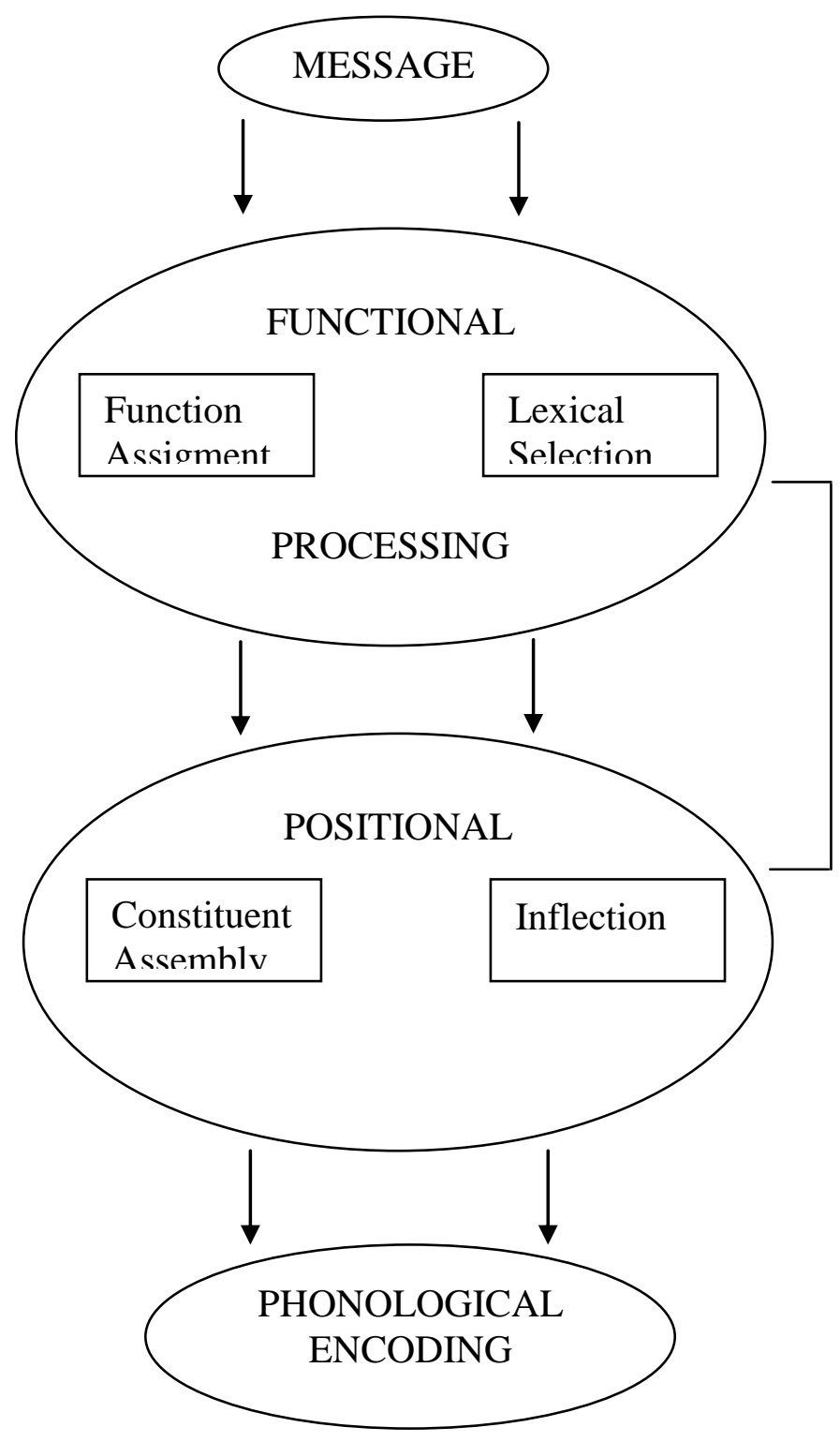

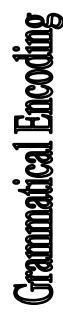

Gambar 1. Tingkat Pemrosesan Ujaran

Skema

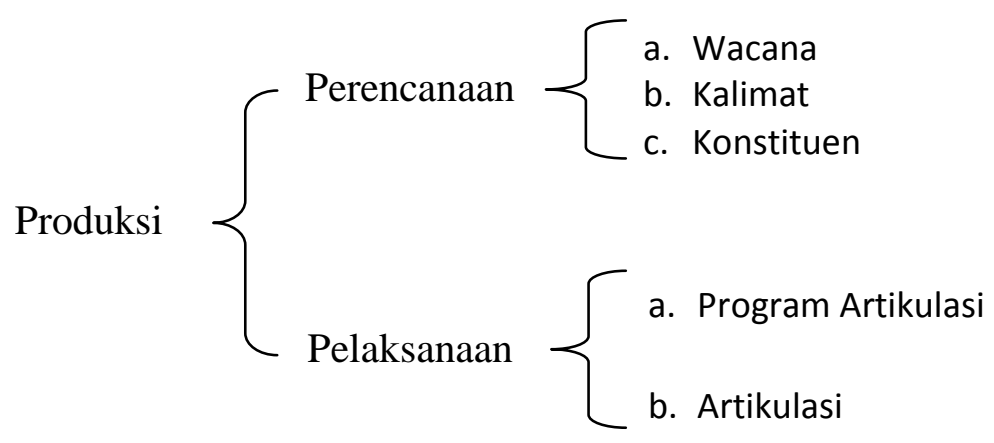


Lampiran

TEKS REKAMAN WAWANCARA

PADA ACARA TALKSHOW KICK ANDY "AKHIRNYA IWAN FALS BICARA"

\begin{tabular}{|c|c|c|c|c|}
\hline No & $A / I$ & Narasi & $\begin{array}{c}\text { Waktu } \\
\text { Kumulatif }\end{array}$ & $\begin{array}{l}\text { Durasi } \\
\text { (Detik) }\end{array}$ \\
\hline 1. & $A$ & $\begin{array}{l}\text { Bayangin, sampai tak datengin ke rumahnya. Aku } \\
\text { bilang ini orang hebatnya apa, sih? }\end{array}$ & $0: 11$ & 11 \\
\hline 2. & 1 & $\begin{array}{l}\text { Saya nggak berdaya juga, hutang janji sama temen- } \\
\text { temen yang datang ke rumah juga akan nonton musik } \\
\text { waktu itu, gimana kalau ep..., kalau main di acaranya } \\
\text { apa ..eh... (Kick Andy) Kick Andy..., semua... mauuuu, } \\
\text { gitu kan. Waduh, sial gue. }\end{array}$ & $0: 27$ & 16 \\
\hline 3. & $\mathrm{~A} / \mathrm{I}$ & (Tertawa bersama) & $0: 30$ & 3 \\
\hline 4. & 1 & $\begin{array}{l}\text { Terus ya..., karena bukan apa apa, emang. Kalo, kalo } \\
\text { nanya kan kadang-kadang ngeri bener ya. (Ha ha ha...) } \\
\text { Dia ada bilang sama istri gue, nanti... udahlah nggak } \\
\text { usah nggak usah nggak usah, gitu. Tapi, ya... memang } \\
\text { memang... ya, memang.... ya nggak biasalah acara } \\
\text { acara kayak gini gitu. }\end{array}$ & $0: 50$ & 20 \\
\hline 5. & $A$ & $\begin{array}{l}\text { Sekarang ke lagu bongkar. (He hem) Itu lagu diciptakan } \\
\text { kapan persisnya? }\end{array}$ & $0: 55$ & 5 \\
\hline 6. & I & $\begin{array}{l}\text { Eh... waktu saya tinggal di condet tahun berapa itu, } \\
\text { tahun... delapan.... sembilah, ya delapan sembilan... } \\
\text { delapan sembilan mungkin (delapan sembilan) } \\
\text { Orientasi waktu saya agak kacau ini. (Kalau orientasi } \\
\text { uang kita semua sama) tahu, tahu (tahu...) Tapi, saya } \\
\text { udah kasih istri saya. }\end{array}$ & $1: 15$ & 20 \\
\hline 7. & $A$ & $\begin{array}{l}\text { Ha ha ha, kasian anak ..... sekarang dia. OK. Jadi } \\
\text { kalau kita lihat lagu bongkar, apa pesan yang ingin } \\
\text { Anda sampaikan waktu itu? }\end{array}$ & $1: 25$ & 10 \\
\hline 8. & $\mathrm{I}$ & $\begin{array}{l}\text { Waktu itu ada... apa, cerita tentang kedung ombo, kaca } \\
\text { piring, way jepara itu, saat itu, jadi... saya agak... } \\
\text { tersentuh itu. }\end{array}$ & $1: 35$ & 10 \\
\hline 9. & $A$ & $\begin{array}{l}\text { Jadi kedung ombo bagi yang belum tahu, itu waktu } \\
\text { sebagian desa itu (di..) dibedol (ya...) untuk dibuat } \\
\text { waduk ya. (ya, waduk) Di situ penderitaan dimulai } \\
\text { waktu itu Anda lihat. }\end{array}$ & $1: 45$ & 10 \\
\hline 10. & I & $\begin{array}{l}\text { Kemudian ada... kasus kaca piring yang... dan ada } \\
\text { way jepara itu di lampung. (Di lampung ya) Lagu itu } \\
\text { seperti itu, kemudian eh...saya dengerin sama jabo, } \\
\text { wah jangan gini dong... dikembangin lagi. (He hem) } \\
\text { Akhirnya kata-kata itu di... apa, di... diganti dengan } \\
\text { 'penindasan serta' itu tadi. Eh, e.. hubungannya sama } \\
\text { swami waktu itu ada grup. Grup itu lahir juga karena... } \\
\text { saat itu memang perlu ada yang dibongkar. (Tapi itu) } \\
\text { Saya pembatalan seratus kota dulu di... di..., di... di... } \\
\text { (Kekecewaan Anda waktu itu) ya, ada ada ada } \\
\text { kekecewaan itu. }\end{array}$ & $2: 21$ & 36 \\
\hline
\end{tabular}




\begin{tabular}{|c|c|c|c|c|}
\hline 11. & $A$ & $\begin{array}{l}\text { Jadi ada tour rencananya ke seratus kota (batal) tapi } \\
\text { kemudian dibatalkan ya. Ini batal itu karena apa } \\
\text { dugaan sementara waktu itu? }\end{array}$ & $2: 28$ & 7 \\
\hline 12. & I & $\begin{array}{l}\text { Nggak ngerti, itu macem-macem ceritanya. Ada yang } \\
\text { bilang persaingan... sponsor, ada yang bilang... politik } \\
\text { saat itu atau... (pemerintah kurang suka ya) } \\
\text { pemerintahan. }\end{array}$ & $2: 36$ & 8 \\
\hline 13. & $A$ & $\begin{array}{l}\text { Ini jaman orde baru soalnya ya (lya, jaman, jaman) Ini } \\
\text { kan jaman orde baru sangat sensitif, kalau sekarang } \\
\text { semua orang berani bicara. Kalau dulu Iwan Fals } \\
\text { dengan lagu bongkarnya itu banyak penderitaan yang } \\
\text { dialami. (He he..) Jadi lagu bongkar memang itu } \\
\text { menyuarakan perasaan yang anda rasakan ketika } \\
\text { melihat situasi dan kondisi yang ada? }\end{array}$ & $2: 55$ & 19 \\
\hline 14. & I & $\begin{array}{l}\text { Iya, sebenarnya sih lebih... iya, dari luar, tapi, ternyata } \\
\text { eh... justru faktor pembongkar yang ada di dalem itu } \\
\text { yang juga justru lebih penting. Eh... apa... eh...... Iwan } \\
\text { versus Iwanlah, kayak gitu itu. Dalam... dalam... }\end{array}$ & $3: 11$ & 16 \\
\hline 15. & $A$ & $\begin{array}{l}\text { Dan dulu pertentangan batin Anda pribadi juga di situ } \\
\text { ya, terungkap dalam lagu bongkar. Nah, sebelum kita } \\
\text { lanjutkan, menarik juga karena saya akan bertanya sola } \\
\text { bahwa selain lagu bongkar, Anda ini kan menulis lagu } \\
\text { bento. Banyak orang menganggap lagu itu } \\
\text { kependekan dari bensi Suharto. Apakah benar anda } \\
\text { benci sama Pak Harto? Anda nggak usah jawab dulu, } \\
\text { karena kita rehat sejenak. Kita akan lanjutkan setelah } \\
\text { pesan-pesan berikut ini. }\end{array}$ & $3: 46$ & 35 \\
\hline
\end{tabular}

Sumber: http://www.youtube.com//Kick Andy//Akhirnya Iwan Fals Bicara.3/25 diunggah oleh nengsalse pada tanggal 5 Februari 2010

\section{Keterangan:}

A : Ujaran Andy F. Noya (pembawa acara Kick Andy, pewawancara)

I : Ujaran Iwan Fals (bintang tamu yang diwawancara)

Huruf cetak tegak : Ujaran Andy F. Noya

Huruf cetak miring : Ujaran Iwan Fals 